Renaissance

and

Reformation
Renaissance

et

Réforme
New Series, Vol. XII, No. 4 Old Series, Vol. XX1V, No. 4
Nouvelle Série, Vol. XII, No. 4 1988 Ancienne Série, Vol. XXIV, No. 4

\title{
Contents / Sommaire
}

ARTICLES

Quand Érasme se fait politique: la première lettre à

Sigismond ler le Vieux

par Danièle Letocha

273

Foreign Impressions of Neapolitan Art in the Sixteenth Century by Beata Stock

291

Predestinarian Theology in the Mid-Tudor Play Jacob and Esau by Paul Whitfield White

303

The World Turned Inside Out: Revolutions of the Infinite Sphere from Hermes to Pascal by Michael $\mathrm{H}$. Keefer

\section{BOOK REVIEWS / COMPTES RENDUS}

315

R.S. White, Innocent Victims: Poetic Justice in Shakespearean Tragedy reviewed by Richard Hillman

318

Records of Early English Drama, Devon, ed. John Wasson, and Ian Lancashire, Dramatic Texts and Records of Britain:

A Chronological Topography to 1558 reviewed by Thomas Pettitt 
324

Robin Headlam Wells, Shakespeare, Politics and the State reviewed by Paul Yachnin

325

Collected Works of Erasmus Volume $27 \& 28$, Literary and

Educational Writings 5 \& 6, ed. A.H.T. Levi reviewed by EJ. Devereux

328

John N. King, English Reformation Literature: The Tudor Origins of the Protestant Tradition reviewed by Donald R. Parker

331

NEWS / NOUVELLES

333

INDEX / TABLE DE MATIERES 1988 